\title{
Problematika Tiga Kota dalam Implementasi Kebijakan Pembatasan Sosial Berskala Besar (PSBB) Masa Pandemi Covid-19 (Studi Kasus: Jakarta, Surabaya, dan Bogor)
}

\author{
Yusuf Perdana $^{1}$, Ajeng Diah Kinanti ${ }^{2}$, Feni Kurniawati ${ }^{3}$, Syahna Ardani ${ }^{4}$ \\ 1,2,3,4 Jurusan Pendidikan Sejarah, Fakultas Keguruan dan Ilmu Pendidikan, Universitas \\ Lampung
}

*Email: yusuf.perdana@fkip.unila.ac.id

\begin{abstract}
Covid-19 cases in Indonesia continue to increase sharply, the latest date is on July 222020 saw reactive patients reaching 91,751 cases, an increase there were 1,882 cases, deaths due to Covid-19 also increased by 139 people, the accumulative total of cases of death was 4,459 people. Assessment the effectiveness of government policies related to efforts to break the chain of transmission of Covid-19 continues to be carried out, including the implementation of social restriction policies large scale (PSBB) enforced in varios major cities in Indonesia. This study aims to analyze various conditions and problems implementation of large scale social restriction policies (PSBB) to allocating social assistance funds in the cities of Jakarta, Surabaya, and Bogor amidst unstable socioeconomic conditions due to the Covid-19 pandemic refers to new habits in living everyday life, remembering these three big cities are cities with the intensity of socio-economic activities population with a heterogeneous background. Method which used in research is a qualitative method with collection techniques library data and interviews. The result of the study show that there are pros and cons to application this large scale social policy $(P S B B)$, even the PSBB is considered useless and does not exist because there are still many fields that are still operating, distribution of social assistance funds that are considered a solution for the community many low income earners are still not on target.
\end{abstract}

Keyword: Covid-19, PSBB, Jakarta, Surabaya, Bogor.

\begin{abstract}
Abstrak
Kasus Covid-19 di Indonesia terus meningkat tajam, data terbaru pada 22 Juli 2020 menunjukkan pasien yang reaktif mencapai 91.751 kasus, peningkatan terjadi sebanyak 1.882 kasus, kematian akibat Covid-19 juga meningkat 139 orang, total akumulatif kasus kematian menjadi 4.459 orang. Pengkajian kefektifan kebijakan pemerintah terkait upaya memutus rantai penularan Covid19 terus dilakukan, tak terkecuali pada penerapan kebijakan pembatasan sosial bersekala besar (PSBB) yang diberlakukan di berbagai kota besar di Indonesia. Penelitian ini bertujuan menganalisis berbagai kondisi serta problematika penerapan kebijakan pembatasan sosial bersekala besar (PSBB) hingga pemberian alokasi dana bantuan sosial di kota Jakarta, Surabaya, dan Bogor ditengah kondisi sosial ekonomi yang tidak stabil akibat pandemi Covid-19 yang merujuk pada kebiasaan baru dalam menjalani kehidupan sehari-hari, mengingat tiga kota besar ini merupakan kota dengan instensitas kegiatan sosial ekonomi yang padat dengan latar belakang penduduk yang heterogen. Metode yang digunakan dalam penelitian adalah metode kualitatif dengan teknik pengumpulan data kepustakaan serta wawacara. Hasil penelitian menunjukan adanya pro kontra terhadap penerapan kebijakan sosial bersekala besar (PSBB) ini, bahkan PSBB dianggap sia-sia dan tak ada karena masih banyaknya bidang-bidang yang tetap beroperasi, penyaluran dana bantuan sosial yang dianggap solusi bagi masyarakat berpenghasilan rendah pun masih banyak yang tak tepat sasaran.
\end{abstract}

Kata Kunci: Covid-19, PSBB, Jakarta, Surabaya, Bogor.

\section{Pendahuluan}

Dunia saat ini sedang mengalami situasi darurat pandemi Covid-19 (Corona Virus Desease 19). Untuk mencegah penyebaran dan juga memutus penularan virus tersebut, Kemendikbud sebagai perwakilan pemerintah membuat kebijakan Pembatasan Sosial Berskala 
Besar (PSBB), yang diterapkan pada berbagai sektor, seperti perekonomian, sosial, budaya, keagamaan, pendidikan, dan sektor-sektor lainnya (Gozali, 2020).

Pada tanggal 31 Maret 2020, Presiden Jokowi mengadakan Konferensi Pers dan mengeluarkan statement bahwa, kebijakan Pembatasan Sosial Berskala Besar (PSBB) merupakan kebijakan yang dipilih dalam merespon adanya Kedaruratan Kesehatan. Kebijakan ini berlandaskan UU No. 6 Tahun 2018 tentang Kekarantinaan Kesehatan.Seiring dipilihnya kebijakan PSBB, Presiden Jokowi menegaskan bahwa Pemerintah Daerah tidak boleh menerapkan kebijakan sendiri-sendiri di wilayahnya, yang tidak sesuai dengan protokol Pemerintah Pusat.Pemerintah pusat dinilai lambat dalam memberikan kebijakan yang bertujuan untuk mencegah adanya virus corona (Nasruddin \& Haq, 2020).

Pemerintah menerapkan peraturan secara menyeluruh, namun tidak semua daerah menerapkan kebijakan PSBB. Dalam kesempatan ini penulis akan memaparkan tentang kebijakan PSBB di daerah Jakarta, Surabaya dan Bogor dimana ketiga kota tersebut merupakan kota besar di Indonesia yang memiliki kepadatan penduduk yang tinggi berakibat pada tingkat penularan virus yang tinggi pula. Namun apakah penerapannya sama di setiap daerahnya, dampak bagi masyarakat, serta upaya-upaya yang dilakukan oleh pemerintah ataupun masyarakat, kemudian keadaaan masyarakat setelah penerapan PSBB di ketiga kota tersebut.

\subsection{Corona Virus Disease 2019 (Covid-19)}

Virus Corona masuk dalam sub famili Coronavirinae dalam keluarga Coronaviridae.menyerang sistem pernafasan pada manusia.Virus corona yang menyebabkan penyakit COVID-19 menginfeksi paru-paru dan mengganggu pernapasan.Dua gejala utama virus corona adalah demam dan batuk kering, yang kadang-kadang dapat menyebabkan masalah pernapasan.Batuk yang harus diwaspadai adalah batuk kering dan terus menerus.Gejala corona lainnya adalah demam yang lebih dari $37.8^{\circ}$. Demam ini bisa membuat penderita merasa hangat, dingin, atau kedinginan, sakit tenggorokan serta sakit kepala.Saat ini belum ada vaksin untuk COVID-19. Namun, para ilmuan sekarang telah mereplikasi virus, sehingga dapat memungkinkan untuk mendeteksi dini dan melakukan pengobatan pada orang yang memiliki virus tetapi belum menunjukkan gejala.National Instutes of Health (NIH) menyatakan bahwa beberapa kelompok orang memiliki risiko tinggi mengalami komplikasi akibat COVID-19. Kelompok-kelompok ini di antaranya: anak muda, orang berusia 65 tahun atau lebih, wanita yang sedang hamil. Untuk itu langkah paling tepat adalah melakukan pencegahan, beberapa cara pencegahannya antara lain: 1) sering-seringlah mencuci tangan dengan sabun dan air selama 20 detik; 2) hindari menyentuh mata, hidung, atau mulut dengan tangan yang tidak dicuci; 3) hindari kontak dekat dengan orang yang sakit; 4) Lindungi orang lain saat sakit dengan memakai masker maupun karantina mandiri(Fatoni, 2020).

\subsection{Pembatasan Sosial Berskala Besar (PSBB)}

Pembatasan Sosial Berskala Besar, yang sering disingkat dengan PSBB adalah peraturan yang diterbitkan Kementerian Kesehatan (Kemenkes) dalam rangka percepatan penanganan COVID-19 agar dapat segera dilaksanakan di berbagai daerah. Aturan PSBB tercatat dalam Peraturan Menteri Kesehatan Nomor 9 Tahun 2020. Sekretaris Jenderal Kementerian Kesehatan, Oscar Primadi dalam keterangan tertulisnya mengatakan PSBB melingkupi pembatasan sejumlah kegiatan penduduk tertentu dalam suatu wilayah yang diduga terinfeksi COVID-19 (Sulasih, 2020).

\section{Metodologi}

Metode yang digunakan dalam penelitian adalah metode kualitatif. Bentuk yang digunakan dalam penelitian ini adalah studi kasus sesuai dengan yang disampaikan oleh Robert K Yin (2008) yakni suatu inquiri empiri dengan menelusuri fenomena dalam kehidupan nyata. 
Penelitian ini menggunakan teknik pengumpulan data menggunakan kepustakaan dan wawancara. Teknik kepustakaan digunakan untuk mendapatkan Informasi dari buku-buku, karya ilmiah, tesis, jurnal, surat kabar, internet, dan sumber-sumber lain yang relevan dengan objek penelitian.Wawancara dalam penelitian ini melibatkan masyarakat yang tinggal di tiga kota besar tersebut, yakni Rayhan Alfarizi dan Septiana sebagai wiraswasta yang bertempat tinggal di Jakarta, Ratu Rahma Safitri dan Erni Handayani selaku wiraswasta di Bogor serta Sukma Indra Cahya dan dan Indari Rochana yang berprofesi sebagai Wiraswasta di Surabaya.

\section{Hasil dan Pembahasan}

\subsection{Upaya yang Dilakukan oleh Pemerintah dan Masyarakat untuk Mencegah dan Melawan Perkembangan CoronaVirus Disease (Covid-19)}

\subsubsection{Jakarta}

Provinsi DKI Jakarta sebagai Ibukota Negara menjadi salah satu wilayah paling banyak terjangkit Covid-19. Per tanggal 18 Mei 2020, terdapat 6.010 orang positif Covid-19 dan sebanyak 483 orang meninggal dunia. Hal ini membuat pemerintah Provinsi DKI Jakarta memberlakukan Social Distancing dan Physical Distancing bahkan menerapkan Pembatasan Sosial Berskala Besar (PSBB). Gubernur Provinsi DKI Jakarta mengeluarkan Peraturan Gubernur Nomor 33 Tahun 2020 tentang Pelaksanaan Pembatasan Sosial Berskala Besar dalam Rangka Penanganan Corona Virus Disease (COVID-19) di Provinsi Daerah khusus Ibukota (DKI) Jakarta (selanjutnya disebut "Pergub DKI Jakarta No. 33 Tahun 2020"), yang ditetapkan dan diundang pada tanggal 9 April 2020. Bentuk pembatasan yang diberlakukan berupa penghentian sementara aktivitas di tempat kerja atau kantor dengan pengecualian bagi usaha di bidang kesehatan, bahan pangan, energi, komunikasi dan teknologi informasi (TI), keuangan, logistik, perhotelan, konstruksi, industri strategis, pelayanan dasar, utilitas publik, dan industri yang ditetapkan sebagai objek vital nasional (Situmeang, 2020).

Pemerintah Provinsi mengeluarkan kebijakan yaitu pencabutan ganjil genap agar masyarakat pengguna transportasi umum berkurang dan beralih ke kendaraan pribadi.Selain itu, Pemerintah juga memperketat aturan transportasi umum dengan menghimbau masyarakat untuk menjaga jarak antar penumpang. Kursi antar penumpang diberi jarak satu hingga dua meter dan jam operasional juga dibatasi, serta wajib menggunakan masker di transportasi umum, maupun saat berjalan kaki. Hal ini pun diperkuat dengan dikeluarkannya Seruan Gubernur Provinsi DKI Jakarta Nomor 9 Tahun 2020 tentang Penggunaan Masker (Nissa et al., 2020). Tidak hanya itu, pemerintah juga mengeluarkan kebijakan berupa larangan ojek online untuk mengangkut penumpang yang dianggap sangat merugikan dan rawan tertular virus Covid-19. Oleh karena itu, ojek online hanya boleh mengangkut barang. Kebijakan itu berdasarkan Peraturan Menteri Kesehatan Nomor 9 Tahun 2020 tentang Pedoman Pembatasan Sosial Berskala Besar (Hartanto dan Nidya Tajsgoani, 2020).

\subsubsection{Surabaya}

Puluhan warga Surabaya mendatangi gedung DPRD Surabaya untuk meminta penghentian pembatasan sosial berskala besar (PSBB) tahap III. Alasannya, kebijakan itu dianggap merugikan warga.Masyarakat yang hadir di DPRD Surabaya tersebut meliputi perwakilan ojek daring, pedagang warung kopi, becak motor, karyawan yang di PHK (pemutusan hubungan kerja), dan warga Surabaya yang terdampak PSBB. Menurut M Sholeh salah satu penggagas dalam slogan "Surabaya Menolak PSBB" dasar perpanjangan PSBB tahap III ini hanya karena penyebaran Covid-19 masih tinggi, tetapi dampak PSBB I dan II yang membuat banyak warga jatuh miskin karena tidak bekerja tidak dijadikan acuan (Kurniawan Dian, 2020).

Padahal pada 20 April 2020 Pemerintah Kota Surabaya sebelumnya sudah berupaya menyelesaikan kajian-kajian sosial ekonomi sebelum nantinya Gubernur Jawa Timur 
mengajukan Pembatasan Sosial Berskala Besar (PSBB) ke Kementerian Kesehatan untuk menanggulangi wabah Covid-19. Muhammad Fikser Kadis Kominfo Kota Surabaya mengatakan, saat ini Pemkot mendata ada 35 ribu Masyarakat Berpenghasilan Rendah (MBR) di Surabaya dan angka tersebut masih berpotensi terus meningkat. Sampai pada Gubernur Jawa Timur Khofifah Indar Parawansa mengadakan pertemuan dengan tiga kepala daerah dari Surabaya, Sidoarjo, dan Gresik di Gedung Grahadi, untuk membahas kemungkinan penerapan PSBB di tiga wilayah tersebut. Dari hasil pertemuan tersebut ketiga kepala daerah sepakat untuk pemberlakuan PSBB (Suminar Agustina, 2020).

\subsubsection{Bogor}

Pemerintah pada wilayah Jawa Barat juga memberlakukan Pembatasan Sosial Berskala Besar (PSBB) di beberapa daerah. Pada wilayah Pemprov Jawa Barat PSBB dilakukan di Kabupaten atau Kota Bogor, Kota Depok, dan Kabupaten/Kota Bekasi (Joharudin et al., 2020). Kebijakan Pembatasan Sosial Berskala Besar (PSBB) di Kabupaten Bogor sendiri secara resmi mulai diterapkan pada hari Rabu, 15 April 2020 bersamaan dengan wilayah Depok, dan Bekasi (Dharmastuti, 2020).

Upaya yang digalakkan pada masa PSBB Kabupaten Bogor salah satunya yaitu penutupan tempat wisata. Lembaga Ilmu Pengetahuan Indonesia (LIPI) melakukan penutupan sementara empat Kebun Raya yang dikelola LIPI, yaitu Kebun Raya Bogor, Kebun Raya Cibodas, Kebun Raya Purwodadi, dan Kebun Raya "Eka Karya" Bali. Pemerintah Kabupaten Bogor juga mengeluarkan kebijakan menutup taman kota dari kegiatan berkumpulnya warga sejak Rabu, 18 Maret 2020. Urusan Sterilisasi juga terus digalakkan, seperti penyemprotan disinfektan. Dari sektor medis, pemeriksaan kesehatan digelar bagi anggota DPRD Kota Bogor bersama wartawan meliputi tekanan darah, suhu tubuh dan cek darah sebagai upaya pencegahan penyebaran covid-19 di Kota Bogor (Dino, 2020).Implementasi kebijakan PSBB juga turut melibatkan personel TNI, Polri, dan Dishub dalam penegakan hukum serta memberikan peringatan kepada seluruh masyarakat di lingkungan tersebut. Selain itu Pemkab Bogor juga membuat buku pegangan yang dapat diketahui oleh semua pihak yang terlibat didalamnya, sehingga seluruh elemen dapat menerapkan kebijakan ini dengan baik (Tuti et al., 2020).

\subsection{Pro dan Kontra Implementasi PSBB Di Tiga Kota (Jakarta, Bogor dan Surabaya) \\ 3.2.1. Jakarta}

Problematika muncul setelah adanya penyebaran Covid-19 dimana pemerintah menetapkan PSBB sebagai langkah revolusioner dalam memutus mata rantai penyebaran dengan mengeluarkan peraturan Menteri Kesehatan Nomor 9 Tahun 2020 tentang Pedoman PSBB. Jakarta merupakan daerah pertama yang menerapkan PSBB dan kemudian diikuti oleh daerah disekitarnya(Hartanto dan Nidya Tajsgoani, 2020). Data deskriptif berdasarkan hasil survei Saiful Munjani dalam Research and Consulting menunjukan analisis kepatuhan masyarakat, pengetahuan, kepercayaan, dan sikap masyarakat terhadap PSBB. Respon masyarakat dinilai positif terhadap penerapan PSBB di DKI Jakarta (Hikmahwati et al., 2020). Pendapat lain menyebutkan bahwa penerapan PSBB kurang efektif, dikarenakan kurangnya kesadaran hukum masyarakat, dampak ekonomi yang menurun, kriminalitas, dan kurangnya ketertiban pengguna jalan, serta penerapan PSBB yang mengalami perpanjangan beberapa kali. Ini merupakan bukti bahwa kesadaran hukum masyarakat belum maksimal dan ekonomi yang terpuruk juga merupakan salah satu penyebab ketidakefektifan penerapan PSBB di DKI (Sulasih, 2020). Dalam pemaparan diatas dapat disimpulkan bahwa penerapan PSBB di Jakarta terdapat beberapa dampak negative yang beragam, mulai dari sisi ekonomi, sosial dan sebagainya.

Disisi lain, banyak problematika yang terjadi saat PSBB diterapkan. Salah satunya yaitu yang dialami ojek online di Jakarta. Problematika ini muncul setelah adanya Peraturan Menteri Perhubungan Nomor 18 Tahun 2020 tentang Pengendalian Transportasi dalam Rangka 
Pencegahan Penyebaran Corona Virus Disease (Covid-19). Peraturan ini menuai banyak kontroversi dan melemahkan Peraturan Menteri Kesehatan dan Peraturan Gubernur yang dapat dilihat dalam Pasal 11 ayat (1) huruf (c) yang menyebutkan: "Sepeda motor berbasis aplikasi dibatasi penggunaannya hanya untuk pengangkutan barang". Sementara di pasal yang sama, huruf (d) menyebutkan "dalam hal tertentu untuk tujuan melayani kepentingan masyarakat dan untuk kepentingan pribadi, sepeda motor dapat mengangkut penumpang dengan ketentuan harus memenuhi protokol kesehatan." Pasal dalam aturan ini mengabaikan Peraturan Menteri Kesehatan dan Peraturan Gubernur menunjukan ketidakpercayaan dan tidak adanya kekompakan dalam pelaksanaan birokrasi guna memutus mata rantai penyebaran Covid - 19 (Hartanto dan Nidya Tajsgoani, 2020).

\subsubsection{Surabaya}

Pelaksanaan PSBB Raya sudah dilakukan sebanyak dua kali dan dalam pelaksanaanya menuai banyak pro kontra dari berbagai pihak. Menurut Joni Wahyuhadi ketua rumpun kuratif gugus tugas penanganan Covid-19 Jawa Timur penegakan terhadap pelaksaan PSBB di Surabaya perlu serius dan ditekankan lagi, masyarakat perlu meningkatkan disiplin dalam memberlakukan hidup bersih dan sehat (Salman Ghinan, 2020). Sedangkan menurut wakil DPRD Kota Surabaya Reni AstutiPenerapan PSBB dari tahap I, tahap II dan tahap III juga tak luput dari perdebatan, mengamati dinamika pro-kontra perpanjangan PSBB Surabaya jilid III ini muncul karena penerapan PSBB jilid I dan II dalam pelaksanaanya belum berhasil melandaikan kurva sehingga menimbulkan perbincangan dan bahasan panjang di grup media sosial. Berbagai saran dan pendapat dari berbagai elemen masyarakat perlu diperhatikan, dan tidak salah jika banyak yang meragukan PSBB jilid III dalam pelaksanaanya akan lebih baik atau perekonomian semakin sulit (FaktaIndonesia.com, 2020).

\subsubsection{Bogor}

Sebelum Kebijakan PSBB Kabupaten Bogor diajukan ke Menteri Kesehatan Terawan Agus Putranto, Pemkot Bogor terlebih dahulu mengkaji terkait dampak ekonomi jika kebijakan tersebut diterapkan nantinya. Wakil Wali Kota Bogor Dedie A Rachim mengaku kendala mengajukan PSBB baginya adalah faktor ekonomi yang harus dipikirkan matang-matang karena terkait angka kemiskinan di kota Bogor. Pasalnya pihaknya harus memikirkan bagaimana menanggung beban kebutuhan masyarakat jika Kota Bogor resmi menerapkan PSBB (Safir, 2020). Perbedaan pandangan antara pemerintah pusat di daerah juga menjadi penghambat keberhasilan implementasi kebijakan PSBB di Kabupaten Bogor.Pemerintah Kabupaten Bogor membutuhkan kewenangan penuh dari pusat untuk bisa mengatur daerahnya sendiri dalam melaksanakan kebijakan PSBB ini.Bupati Bogor Ade Yasin meminta kewenangan penuh untuk melakukan tindakan preventif selama penerapan Pembatasan Sosial Skala Besar (PSBB). Pasalnya, Pemkab Bogor masih memiliki kesulitan membuat pembatasan yang lebih ketat karena bertabrakan dengan peraturan pusat. Misalnya, tidak dapat memblokir sebagian jalan untuk memilih siapa yang boleh masuk atau tidak masuk Kabupaten Bogor (Tuti et al., 2020).

\subsection{Kondisi Masyarakat Pasca Penerapan PSBB}

\subsubsection{Jakarta}

Pemerintah Provinsi DKI Jakarta memperpanjang masa PSBB transisi karena kasus positif Covid-19 masih terus bertambah, sehingga PSBB akan diterapkan sampai keadaan membaik. Pemerintah Provinsi DKI Jakarta sudah melakukan dua kali perpanjangan masa PSBB transisi.Masa PSBB transisi berakhirpada 4 Juni.Setelahitu, Pemerintah Provinsi DKI Jakarta memutuskan untuk memperpanjang PSBB. Kemudian, PSBB tahap keempat diperpanjang sampai 2 Juli 2020 dan PSBB inimenjadi PSBB masatransisimenuju new normal 
di Jakarta. Kebijakan ini akan terus diperpanjang sampai kasus positif Covid-19 menurun (Sari Nursita, 2020).

Dampak dari penerapan PSBB sangat terasa bagi keadaan masyarakat Jakarta terutama di bidang ekonomi dan bidang sosial masyarakatnya. Pada bidang ekonomi mengalami penurunan pendapatan bagi setiap masyarakat yang bekerja, karena adanya PSBB membuat beberapa perusahaan, toko, dan kegiatan perekonomian yang lainnya ditutup sementara, dan menyebabkan banyak karyawan/buruh kehilangan pekerjaanya (Hadiwardoyo, 2020). Selain itu, tidak hanya dampak ekonomi yang dirasakan masyarakat tetapi juga keadaan sosial masyarakat yang sangat tertekan dengan adanya wabah Corona Virus Disease (Covid19).Banyaknya kasus positif Covid-19 dan meningkatnya kasus kematian membuat masyarakat merasa takut, cemas, dan rasa ketidakpastian dengan adanya wabah ini. Pemerintah melakukan berbagai upaya untuk menangani dampaks dari menurunnya pendapatan masyarakat dengan mengeluarkan bantuan berupa bansos dan bantuan berupa sosialisasi kepada masyarakat agar tetap tenang dan selalu menjaga daya tahan tubuh agar tidak stressdan tetap sehat (Hidayati et al., 2020).

Dampak penerapan kebijakan PSBB membuat kegiatan perekonomian terhenti di beberapa tempat. Keadaan tersebut membuat sebagian masyarakat Jakarta harus mencari pekerjaan baru yang bisa mereka lakukan di tengah pandemic saatini. Sebagai contoh yaitu berjualan dengan memanfaatkan media sosial, barang yang dijual beragam mulai dari pakaian, makanan, perabotanrumah, aksesoris, dansebagainya. PSBB yang dilaksanakan di Jakarta ternyata dinilai masyarakat belumberhasil, dengan kata lain mereka merasa masih jauh dari kata stabil. Keadaan tersebut disebabkan karena kurangnya kesadaran masyarakat dengan peraturan yang dibuat (Septiana, 2020).

\subsubsection{Surabaya}

Setelah diberlakukanya PSBB di Surabaya, Pemerintah Kota Surabaya terus menyalurkan bantuan dana sosial bagi masyarakat berpenghasilan rendah pada tahap I kepada sekitar 3 ribu lebih kepala keluarga dari total 65.908 warga Surabaya yang menerima bansos tunai dari Kementerian Sosial. Sementara itu pada tahap II akan diberikan kepada 10.033 kepala keluarga yang akan mendapatkan bansos tunai sebesar RP 600 ribu selama tiga bulan, Mei Juni, dan Juli sementara itu, pengambilan bansos dilakukan di Kantor Pos Kebon Rejo (Wijayanto, 2020). Meskipun pasien Covid-19 di Surabaya menunjukan ke arah yang positif untuk kesembuhan dan kesehatan, namun Pemkot Surabaya terus mengimbau kepada warga untuk terus mencegah penularan Covid-19 di Surabaya dengan terus banyak minum vitamin C, rajin berolahraga dan istirahat teratur agar imun tubuh tetap stabil. Upaya preventif ini memang harus dilakukan untuk mencegah tertularnya virus tersebut.Karena itu, Wali Kota Surabaya Tri Rismaharini berharap kepada pemimpin perusahaan agar mengizinkan pegawainya keluar saat pagi untuk berjemur di bawah terik matahari minimal 15 menit (Wijayanto, 2020).Longgarnya penerapan Pembatasan Sosial Berskala Besar (PSBB) di Surabaya menjadi salah satu alasan dibalik tingkat penyebaran yang membawa ibu kota pronvinsi Jawa Timur itu ke dalam "zona hitam", menurut pakar kesehatan dan tenaga medis. Jawa Timur adalah provinsi dengan jumlah kasus kumulatif kedua tertinggi di Indonesia, setelah DKI Jakarta, sejak wilayah itu mengalami lonjakan yang tajam pada akhir bulan Mei 2020 (Tambunan, 2020).

Menurut penuturan Sukma Indra Cahya yang berprofesi sebagai wiraswasta menjelaskan selama penerapan PSBB di kota Surabaya kegiatan perekonomian di pasar Sidoarjo tetap berjalan namun dibuka seminggu 3 kali, namun di lingkunganya masih terdapat pasar malam dan masih banyak orang-orang yang berkerumun (Cahya, 2020). Sedangkan menurut Indari Rochana seorang wiraswasta berpendapat bahwa lingkungan tempat tinggalnya di perum griya karya sedati PSBB berjalan dengan baik, meskipun penerapanya juga berdampak pada semakin menurunya gaji karyawan (Rochana, 2020). 
Sementara itu dampak sosial yang dirasakan masyarakat bahwa PSBB tidak efektif karena tidak tegas dalam mengatur hak dan kewajiban antara pemerintah dan masyarakat, karena tidak dibarengi dengan penjaminan pemenuhan kebutuhan masyarakat maka pemerintah juga tidak bisa memaksa masyarakat menuruti semua imbauan. Masyarakat akan disiplin jika aturanya jelas, sanksinya juga jelas, dan penegakan hukumnya konsisten (Fatoni, 2020). PSBB telah mampu mengurangi resiko infeksi karena kebijakan tersebut telah mengakibatkan setiap orang untuk menahan diri untuk tidak keluar dan bertemu di depan umum. Namun, otoritas kesehatan Jawa Timur melaporkan bahwa PSBB belum bisa melandaikan kurva kasus Covid19 yang terkonfirmasi di Surabaya (Andriani, 2020).

\subsubsection{Bogor}

Jelang berakhirnya masa pembatasan sosial berskala besar (PSBB) Transisi pada 2 Juli 2020, sektor perekonomian di Kota dan Kabupaten Bogor mulai menggeliat. Salah satunya, okupansi hotel yang mulai terkerek naik di angka 57,88 persen. Menggeliatnya ekonomi di masa PSBB Proporsional juga terjadi di Kabupaten Bogor. Banyaknya wisatawan yang berkunjung ke Puncak membuat okupansi hotel yang sebelumnya stagnan meningkat di angka 40-50 persen (Yosep, 2020).

Pemerintah Kota Bogor mencatat sebanyak $40 \%$ warganya kehilangan pekerjaan selama pandemi (Wijaya, 2020). Hal itu karena banyak bidang yang sudah kembali beroperasi dengan mengedepankan protokol kesehatan. Kemudian untuk sektor yang masih belum diperbolehkan kembali beroperasi hanya pendidikan. Sementara, bidang yang mulai dibuka secara perlahan yakni wisata dan olahraga (Astyawan, 2020). Selain itu PSBB juga berdampak positif pada perubahan kualitas udara yang cukup signifikan. Pasca penerapan PSBB, pengukuran kualitas udara di beberapa kota di Indonesia mengalami perbaikan kualitas yang signifikan. Kawasan Bogor mengalami peningkatan kualitas udara tertinggi se-Indonesia selama periode Januari hingga April 2020 yaitu sebesar 44,9 persen (Ariatullah, 2020).

Keadaan di Kota Bogor pada saat penerapan PSBB cenderung sepi, namun tetap menerapkan protokol kesehatan, karena apabila tidak memakai masker akan dikenakan sanksi seperti menghafal pancasila atau membersihkan sampah di lingkungan sekitar (Safitri, 2020).

Berdasarkan keterangan dari Erni Handayati (49 tahun) seorang wiraswata, PSBB Kabupaten Bogor berakibat pada penurunan pendapatan saat berdagang karena sepi pelanggan. Hasil yang didapat dari berdagang pun hanya cukup untuk memenuhi kebutuhan sehari-hari. Oleh karena itu, ibu Erni menyiasati keadaan tersebut dengan cara menambahkan barang dagangan yang banyak dicari orang saat ini seperti pot bunga, pupuk dan sebagainya. Perubahan sosial yang terjadi pasca diterapkannya PSBB relatif sama dengan daerah lainnya seperti orangorang yang memakai masker dan menerapkan protokol kesehatan lainnya(Handayani, 2020).

\section{Kesimpulan}

Virus Corona atau Covid-19 telah menyebar luas ke berbagai wilayah Indonesia termasuk tiga kota besar di Pulau Jawa yaitu Jakarta, Surabaya, dan Bogor. Sekelumit permasalahan turut mengiringi upaya pemerintah dalam menerapkan PSBB guna mengurangi penyebaran Covid-19.Penerapan PSBB di awali dari Jakarta yang pertama kali menerapkan PSBB sebagai Ibukota Negara yang memiliki jumlah penduduk yang padat, kemudian disusul oleh Bogor dan Surabaya.Melalui kebijakan PSBB ini pemerintah menutup tempat-tempat umum seperti mall, tempat rekreasi, dan lainnya serta melakukan sterilisasi. Banyak upaya preventif pula yang dilakukan secara mandiri oleh masyarakat. Bukan tanpa kekurangan, kebijakan PSBB di tiga kotaini menimbulkan banyak pro dan kontra. Penerapan PSBB di Jabodetabek sendiri ada yang menilai pelaksanaannya terlambat, ada juga yang menilai sudah cukup tepat. Sementara di Surabaya pro kontra terjadi pada perpanjangan PSBB, dimana penerapan PSBB jilid I dan II dinilai kurang efektif melandaikan kurva kasus virus 
corona.PSBB memiliki dampak yang cukup besar bagi masyarakat. Masyarakat di kota Jakarta mengalami penurunan pendapatan bahkan kehilangan pekerjaan, di samping itu juga mempengaruhi kehidupan sosial dimana masyarakat ketakutan tehadap penyebaran Covid-19 yang cukup besar di Jakarta. Berbeda dengan Jakarta, penurunan pendapatan masyaramat di Surabaya dan Bogor harus ditambah lagi dengan ketidakpastian penjaminan akan kebutuhan hidup oleh pemerintah sehingga masyarakat semakin kesulitan. Meskipun demikian PSBB di kota Bogor nyatanya dapat menurunkan angka kasus penyebaran Covid-19, maka pemerintah kota Bogor terus memperpanjang PSBB di wilayahnya.

\section{Saran}

Perlunya penelitian lebih lanjut terhadap dampak dari penerapan kebijakan pembatasan sosial berskala besar (PSBB) sebagai bahan pertimbangan dalam kelanjutan penerapan PSBB atau sebagai literatur ataupun wawasan untuk pemerintah khususnya dan seluruh masyarakat pada umumnya.

\section{Daftar Pustaka}

Andriani, H. (2020). Effectiveness of Large-Scale Social Restrictions (PSBB) toward the New Normal Era during COVID-19 Outbreak: a Mini Policy Review. Journal of Indonesian Health Policy and Administration, 5(2), 61-65. https://doi.org/10.7454/ihpa.v5i2.4001

Ariatullah, R. (2020). Analisis Big Data dan Birunya Langit Bogor Sebagai Dampak Covid-19. https://www.radarbogor.id/2020/06/26/analisis-big-data-dan-birunya-langit-bogorsebagai-dampak-covid-19

Astyawan, P. R. . (2020). PSBB Proporsional di Bogor, Wali Kota Nilai Perekonomian Perlahan Mulai Pulih. Megapolitan. Okezone. Com. https://megapolitan.okezone.com/read/2020/07/20/338/2249427/psbb-proporsional-dibogor-wali-kota-nilai-perekonomian-perlahan-mulai-pulih

Cahya, S. . (2020). Interview.

Dharmastuti, H. (2020). Catat! Ini Daftar Aturan PSBB di Bogor, Depok dan Bekasi yang Berlaku Hari Ini. Detik.Com. https://news.detik.com/berita/d-4977383/catat-ini-daftaraturan-psbb-di-bogor-depok-dan-bekasi-yang-berlaku-hari-ini

Dino, O. (2020). Ragam Upaya Bogor Mencegah Penyebaran Virus Corona. https://foto.kompas.com/photo/read/2020/03/20/15846759024eb/ragam.upaya.bogor.men cegah.penyebaran.virus.corona

FaktaIndonesia.com. (2020). DPRD Ingin PSBB Surabaya Jilid 3 Jadi yang Terakhir. https://www.faktaindonesianews.com/fakta-peristiwa/24356/dprd-ingin-psbb-surabayajilid-3-jadi-yang-terakhir.html\#

Fatoni, A. (2020). Dampak covic 19 dan kebijakan PSBB pemerintah terhadap UMKM di wilayah Wiyung Surabaya. Dinar: Jurnal Prodi Ekonomi Syari'ah., 3(1), 39.

Gozali, A. (2020). Jurnal Bimbingan Konseling Pendidikan Islam Coution: Journal of Counseling and Education Layanan Bimbingan Dan Konseling Berbasis Teknologi Informasi Pada Masa PSBB (Pembatasan Sosial Berskala Besar). Jurnal Bimbingan Konseling Pendidikan Islam Coution : Journal of Counseling and Education, 1, 36-49.

Hadiwardoyo, W. (2020). Kerugian Ekonomi Nasional Akibat Pandemi Covid-19. Baskara Journal of Business and Enterpreneurship, 2(2), 83-92. 
https://doi.org/10.24853/baskara.2.2.83-92

Handayani, E. (2020). Interview.

Hartanto dan Nidya Tajsgoani. (2020). Dualisme Pengaturan Ojek Online Angkut Penumpang dalam Pembatasan Sosial Berskala Besar (PSBB) di Jakarta. Jurnal Al- 'Adl, 13(2), 253267.

Hidayati, D., Prasojo, A. P. ., Kusumaningrum, D., Surtiari, G. A. ., \& Aini, Y. . (2020). Riset dampak PSBB: meski menerima bantuan pemerintah, warga hanya mampu bertahan seminggu. The Conversation. https://theconversation.com/riset-dampak-psbb-meskimenerima-bantuan-pemerintah-warga-hanya-mampu-bertahan-seminggu-140180

Hikmahwati, Sangadji, E., \& Utami, R. R. M. (2020). Impact Analysis of the Large-Scale Social Restrictions (PSBB) Policy Implementation in Jakarta. Journal Of Indonesian Health Policy And Administration, 5(2), 57-60.

Joharudin, A., Septiadi, M. A., Maharani, S., Aisi, T. D., \& Nurwahyuningsih, N. (2020). Panic Syndrom Covid-19 : Penekanan Terhadap Kebijakan Yang Diberikan. Jurnal Perspektif, 4(1), 44-53.

Kurniawan Dian. (2020). Puluhan warga Surabaya minta PSBB tahap III dihentikan Mengapa? https://www.liputan6.com/tag/psbb-surabaya

Nasruddin, R., \& Haq, I. (2020). Pembatasan Sosial Berskala Besar (PSBB) dan Masyarakat Berpenghasilan Rendah. SALAM: Jurnal Sosial Dan Budaya Syar-I, 7(7). https://doi.org/10.15408/sjsbs.v7i7.15569

Nissa, N. K., Nugraha, Y., Finola, C. F., Ernesto, A., Kanggrawan, J. I., \& Alex L. Suherman. (2020). Evaluasi Berbasis Data: Kebijakan Pembatasan Mobilitas Publik dalam Mitigasi Persebaran COVID-19 di Jakarta. Jurnal Sistem Cerdas, 3(2), 84-94.

Rochana, I. (2020). Interview.

Safir, M. (2020, April). Angka Kemiskinan Hambat Bogor Siapkan PSBB Lawan Corona. 7 April. $\quad$ https://m.cnnindonesia.com/nasional/20200407160632-20-491297/angkakemiskinan-hambat-bogor-siapkan-psbb-lawan-corona

Safitri, R. . (2020). Interview.

Salman Ghinan. (2020, April). Pemkot Surabaya telah lakukan pencegahan penyebaran corona, ini alasan kasus positif masih tinggi. https://surabaya.kompas.com/read/2020/04/15/14422021/pemkot-surabaya-telahlakukan-pencegahan-penyebaran-corona-ini-alasan-kasus?page=all

Sari Nursita. (2020). Psbb Di Jakarta Diperpanjang 14 Hari. 6 Juni. https://megapolitan.kompas.com/read/2020/06/04/13114051/psbb-jakarta-masa-transisikegiatan-sosial-ekonomi-dilakukan-bertahap

Septiana, D. (2020). Interview.

Situmeang, T. (2020). Keberadaan Denda Administratif Terkait Peraturan Gubernur Dki Jakarta Nomor 33 Tahun 2020 Tentang Pelaksanaan Psbb Dalam Penanganan Covid-19 Di Provinsi Dki Jakarta. Jurnal Hukum: Hukum Untuk Mengatur Dan Melindungi 
Masyarakat, 6, 156-169.

Sulasih, R. E. S. (2020). Ketidakefektifan Penerapan Pembatasan Sosial Berskala Besar (PSBB) di Daerah Khusus Ibukota Jakarta. Jurnal Binamulia Hukum, 9(1). https://doi.org/https://doi.org/10.37893/jbh.v9i1.104

Suminar Agustina. (2020). Pemkot Surabaya siapkan kajian sosial ekonomi penerapan PSBB.

Tambunan, L. (2020). Covid-19 di Surabaya masuk kategori 'Zona Hitam', perilaku warga 'seperti tidak ada PSBB.' https://www.bbc.com/indonesia/indonesia-52905012

Tuti, R. W., Murod, M., \& Patrianti, T. (2020). Implementation of Large-Scale Social Restrictions Policy ( PSBB ) in Bogor District Government. Jurnal Manajemen Pelayanan Publik, 4(1).

Wijayanto. (2020). Tak sesuai sasaran, 3 ribu penerima Bansos tunai ganti nama penerima. https://radarsurabaya.jawapos.com/read/2020/05/19/194993/tak-sesuai-sasaran-3-ribupenerima-bansos-tunai-ganti-nama-penerima

Yosep. (2020). Jelang Berakhirnya PSBB Transisi, Ekonomi Bogor Mulai Menggeliato Title. https://www.radarbogor.id/2020/06/29/jelang-berakhirnya-psbb-transisi-ekonomi-bogormulai-menggeliat/

Wijaya, L. D. (2020). Bima Arya Tolak PSBB Total, Fokus Dampak Ekonomi dan Rendahnya Pemahaman Warga. https://metro.tempo.co/read/1385420/bima-arya-tolak-psbb-totalfokus-dampak-ekonomi-dan-rendahnya-pemahaman-warga. 